\title{
PENGARUH PIJAT PERINEUM TERHADAP TINGKAT KECEMASAN IBU TRIMESTER III DI PUSKESMAS MANYARAN
}

\author{
Heny Prasetyorini*,Niken Sukesi**
}

Akademi Keperawatan Widya Husada, Jl Subali Raya no 12 Semarang

\section{Article Info}

\section{Article History:}

\section{Key words:}

Pijat Perineum, Ibu

Hamil, Kecemasan

Corresponding author:

Pendahuluan : Kehamilan merupakan periode krisis situasi yang menimbulkan stress oleh karena perubahan psikologi saat kehamilan. Ibu cemas akan adanya rasa nyeri proses persalinan serta cemas akan kondisi bayi yang dilahirkannya (Bobak,2006). Rasa cemas akan menimbulkan kondisi abnormal saat proses persalinan. Intervensi yang bisa diberikan adalah dengan memberikan penyuluhan kesehatan persiapan menjelang persalinan seperti pijat perineum. Pijat adalah intervensi yang masuk dalam pendekatan nonfarmakologi untuk mengurangi rasa sakit yang dilakukan saat kehamilan (Gadysa, 2009). Apabila pijat perineum dilakukan secara tepat akan menurunkan nyeri persalinan yang disebabkan karena nyeri robekan perineum dan jahitan sekaligus mengurangi rasa khawatir terhadap persalinan yang akan dihadapi (Indivara, 2009 dan Aprilia, 2010).

Tujuan : Untuk mengetahui pengaruh pijat perineum terhadap tingkat kecemasan pada ibu hamil trimester 3

Metode : Menggunakan metode penelitian analitik komparasi karena peneliti mencoba mengkaji adanya pengaruh pijat perineum terhadap kecemasan pada ibu trimester 3 dengan pendekatan cross sectional.

Hasil : Responden penelitian rerata memiliki riwayat persalinan tidak bermasalah, pendidikan SLTA, Pekerjaan IRT, Kehamilan Pertama dan usia $<25$ tahun. Uji statistik menggunakan Uji Mc Nemar menunjukan terdapat pengaruh pada ibu hamil trimester 3 yang melakukan pijat perineum terhadap penurunan tingkat kecemasan, ibu yang sebelum diajarkan pijat perineum dengan tingkat kecemasan ringan sebanyak 4 menurun menjadi 0 atau tidak memiliki kecemasan setelah ibu melakukan pijat perineum sedangkan ibu yang sebelumnya memiliki tingkat kecemasan sedang sebanyak 11 menurun menjadi kecemasan ringan sebanyak 3 setelah diajarkan pijat perineum.

Diskusi : Hasil penelitian menyarankan bahwa pijat peineum bisa dijadikan intervensi keperawatan mandiri dalam menurunkan tingkat kecemasan pada ibu hamil trimester 3. 
Kesimpulan : Terdapat pengaruh pijat perineum terhadap tingkat kecemasan pada ibu hamil trimester 3 .

Introduction: Pregnancy is a period of crisis situations that cause stress due to psychological changes during pregnancy. Mother is worried about the pain of labor process and worry about the condition of the baby that she born (Bobak, 2006). Anxiety will cause abnormal conditions during labor. Interventions that can be given is to provide health education preparations before delivery like perineal massage. Massage is an intervention that enters the nonpharmacology approach to reduce pain during pregnancy (Gadysa, 2009). When proper perineal massage will reduce labor pain caused by perineal rupture and stitches pain while reducing the fear of delivery to be faced (Indivara, 2009 and Aprilia, 2010). Objective: To determine the effect of perineal massage on anxiety levels in pregnant women trimester 3

Method: Using comparative analytic research method because the researcher tried to study the influence of perineal massage on anxiety in trimester mother 3 with cross sectional approach.

Results: Average research respondents had a history of non-problematic delivery, high school education, IRT work, first pregnancy and $<25$ years of age. The statistical test using Mc Nemar Test showed that there was an effect on trimester pregnant women 3 who did perineal massage to decrease the level of anxiety, mother who before taught perineal massage with level of light anxiety as much 4 decreased to 0 or did not have anxiety after mother doing perineal massage while mother previously had a moderate anxiety level of 11 decreased to mild anxiety as much as 3 after being taught perineal massage.

Discussion: The results suggest that perineum massage can be an independent nursing intervention in lowering anxiety levels in pregnant women of 3 rd trimester.

Conclusion: There is influence of perineal massage on anxiety level in pregnant mother of trimester 3. 


\section{PENDAHULUAN}

Kehamilan merupakan suatu periode krisis situasi yang dapat menimbulkan stress dikarenakan oleh perubahan psikologi yang terjadi saat kehamilan. Dan rasa cemas itu hadir saat menjelang proses persalinan pada trimester 3. Ibu cemas akan adanya rasa nyeri saat proses persalinan serta cemas akan kondisi bayi yang dilahirkannya (Bobak,2006). Akibat dari kecemasan yang tidak tertangani dapat mengakibatkan kondisi abnormal saat proses persalinan.

Kecemasan adalah gangguan alam perasaan yang ditandai dengan perasaan ketakutan dan kekhawatiran yang mendalam dan berkelanjutan (Stuart, 2007). Adapun faktor - faktor yang mempengaruhi kecemasan adalah faktor internal meliputi pendidikan, pengetahuan dan penyakit yang dialami, faktor eksternal meliputi dukungan keluarga, tenaga medis, lingkungan fisik, sosial dan dan biologis. Gejala yang timbul yang biasa dialami pada ibu hamil menjelang persalinan ibu akan tampak khawatir, jantung berdebar - debar, gangguan tidur, gangguan pencernaan serta sakit kepala (Hidayat, 2006).

Intervensi yang bisa diberikan untuk ibu hamil menjelang persalinan adalah dengan memberikan penyuluhan kesehatan terkait dengan persiapan persalinan salah satu diantaranya adalah pijat perineum dan hypnobrithing untuk mengurangi rasa nyeri persalinan. Pijat adalah intervensi yang masuk dalam pendekatan nonfarmakologi untuk mengurangi rasa sakit yang dilakukan saat kehamilan, stimulasi kuteneus, aroma terapi, hypnotis, akupuntur dan yoga (Gadysa, 2009).

Pijat perineum merupakan teknik memijat perineum yang dilakukan 2 minggu sebelum persalinan bermanfaat untuk melembutkan jaringan ikat, melancarkan peredaran darah, relaksasi. Tindakan ini dapat membatu mencegah terjadinya rupture perineum dan nyeri luka post episiotomy dan nyeri jahitan luka perineum. Apabila pijat perineum dilakukan secara tepat akan menurunkan nyeri persalinan yang disebabkan karena nyeri robekan perineum dan jahitan sekaligus mengurangi rasa khawatir terhadap persal;inan yang akan dihadapi (Indivara, 2009 dan Aprilia, 2010).

\section{METODE}

Metode penelitian ini dilakukan dengan cara peneliti mencari responden sesuai dengan kriteria inklusi yang telah ditetapkan yaitu pada ibu hamil trimester ke 3 yang sedang melakukan pemeriksaan Antenataal Care di Puskesmas Manyaran sejumlah 18 responden. Setelah mendapatkan responden peneliti memberikan kuasioner pada Ibu hamil untuk mengisi kuasioner Kecemasan setelah itu ibu hamil diajarkan pijat perineum untuk persiapan menjelang persalinan, di harapkan dengan di ajarkannya pijat perineum pada ibu hamil trimester 3 dapat mengurangi kecemasan pada ibu hamil. ibu akan lebih siap menjelang proses persalinan. setelah di ajarkan ibu hamil akan diberikan kuasioner kecemasan kembali, untuk melihat pengaruh kecemasan ibu hamil menjelang proses persalinan sebelum dan setelah di ajarkan pijat perineum. Jenis penelitian ini adalah Quasy eksperimental dengan desain statistic group comparison.

Dalam penelitian ini menggunakan metode penelitian analitik komparasi karena peneliti mencoba mengkaji adanya pengaruh pijat perineum terhadap kecemasan pada ibu trimester 3. Pendekatan yang digunakan adalah cross sectional.

\section{HASIL}

Hasil penelitian berupa analisis univariat dan bivariat. Pada analisis bivariat akan disampaikan mengenai karakteristik responden berupa agama, suku, riwayat persalinan, pendidikan, pekerjaan, riwayat kehamilan, umur, tingkat kecemasan sebelum diajarkan pijat perineum dan setelah diajarkan pijat perineum. Analisis bivariat pada penelitian ini untuk mengetahui pengaruh pijat perineum terhadap tingkat kecemasan pada ibu hamil trimester 3. 


\section{Analisis Univariat}

Tabel 1. Distribusi frekuensi karakteristik responden pijat perineum

\begin{tabular}{lcc}
\hline \multicolumn{1}{c}{ Karakteristik } & \multicolumn{2}{c}{ Frekuensi } \\
& $\mathrm{N}$ & $\%$ \\
\hline Riwayat & & \\
persalinan & & \\
Bermasalah & 1 & $5.60 \%$ \\
Tidak bermasalah & 16 & $88.90 \%$ \\
Perdarahan & 1 & $5.60 \%$ \\
\hline Pendidikan & & \\
SD & 5 & $27.80 \%$ \\
SLTA & 12 & $66.70 \%$ \\
PT & 1 & $5.60 \%$ \\
\hline Pekerjaan & & \\
IRT & 13 & $72.20 \%$ \\
Pedagang & 1 & $5.60 \%$ \\
Karyawan swasta & 4 & $22.20 \%$ \\
\hline Riwayat & & \\
Kehamilan & & \\
Pertama & 10 & $55.60 \%$ \\
Kedua & 8 & $44.40 \%$ \\
\hline Umur & & \\
$<25$ & 13 & $72.20 \%$ \\
$25-35$ & 4 & $22.20 \%$ \\
$>35$ & 1 & $5.60 \%$ \\
\hline
\end{tabular}

Berdasarkan tabel frekuensi karakteristik diatas didapatkan hasil $100 \%$ responden beragama islam dan bersuku jawa, Riwayat persalinan bermasalah 1 responden $(5.6 \%)$, tidak bermasalah 16 responden $(88.9 \%)$, perdarahan 1 responden $(5.6 \%)$, Pendidikan SD 5 responden $(27.8 \%)$, SLTA 12 responden (66.7\%), PT 1 responden (5.6\%). Pekerjaan IRT 13 responden $(72.2 \%)$, Pedagang 1 responden (5,6\%), Karyawan Swasta 4 responden (22.2\%). Riwayat kehamilan Pertama 10 responden $(55.6 \%)$, Kedua 8 responden (44.4\%), Umur $<2513$ responden $(72.2 \%), 25-353$ responden $(22.2 \%),>351$ responden $(5.6 \%)$.

\section{Analisis Bivariat}

Tabel 2. Distribusi responden berdasarkan pengaruh pijat pada ibu hamil trimester 3 terhadap tingkat kecemasan sebelum dan sesudah dilakukan pijat perineum

\begin{tabular}{ccc}
\hline $\begin{array}{c}\text { Tingkat } \\
\text { kecemasan }\end{array}$ & Sebelum & Sesudah \\
\hline $\begin{array}{c}\text { Kecemasan } \\
\text { ringan }\end{array}$ & 4 & 0 \\
\hline $\begin{array}{c}\text { Kecemasan } \\
\text { sedang }\end{array}$ & 11 & 3 \\
\hline
\end{tabular}

Berdasarkan tabel analisis bivariat pengaruh pijat perineum pada ibu hamil trimester 3 terhadap tingkat kecemasan sebelum dan sesudah diajarkan pijat perineum. Didapatkan data responden yang mengalami kecemasan ringan sebelum dilakukan pijat perineum sebanyak 4 responden dan setelah dilakukan pijat perineum menjadi 0 responden, sedangkan responden yang mengalami kecemasan sedang sebelum diajarkan pijat perineum sebanyak 11 responden dan setelah diajarkan pijat perineum menjadi sebanyak 3 responden.

Analisis data yang digunakan dengan menggunakan Uji Mc Nemar yaitu dengan membandingkan sebelum dan sesudah diajarkan pijat perineum.

\section{PEMBAHASAN}

Secara umum penelitian ini bertujuan untuk mengetahui pengaruh pijat perineum terhadap tingkat kecemasan ibu hamil trimester 3 di Puskesmas Kota Semarang. Adapun karakteristik responden yang didapatkan dari penelitian Riwayat persalinan bermasalah terdapat 1 responden $(5.6 \%)$, tidak bermasalah terdapat 16 responden $(88.9 \%)$, perdarahan terdapat 1 responden $(5.6 \%)$.

Hasil dari penelitian terdapat $16 \mathrm{ibu}$ tidak bermasalah dalam riwayat persalinannya. Menurut penelitian yang dilakukan oleh Rifdiani (2016) yang menyatakan bahwa ada pengaruh riwayat perdarahan postpartum terhadap kejadian perdarahan postpartum dan merupakan faktor risiko terjadinya perdarahan postpartum. Persalinan buruk pada persalinan sebelumnya merupakan keadaan yang perlu untuk diwaspadai. Riwayat persalinan dengan perdarahan postpartum sebelumnya memberikan trauma buruk pada organ reproduksi seorang perempuan, sehingga dengan demikian ibu trimester 3 yang memiliki 
riwayat persalinan bermasalah saat menjelang persalinan pasti memiliki tingkat kecemasan yang tinggi di bandingkan dengan ibu yang tidak memiliki riwayat persalinan yang bermasalah.

Riwayat pendidikan terdapat ibu yang memiliki pendidikan SD sebanyak 5 responden $(27.8 \%)$, SLTA 12 responden (66.7\%), PT 1 responden (5.6\%). Pendidikan berpengaruh terhadap kecemasan ibu menjelang persalinan. Di dalam penelitian terbanyak ibu berpendidikan SLTA sebanyak 12 responden, hasil penelitian menunjukan ibu yang sebelumnya memiliki kecemasan ringan menjadi tidak cemas dan ibu yang memiliki kecemasan sedang sebelumnya 11 responden berkurang menjadi 3 responden dan kecemasanya pun menurun kecemasan ringan. Menurut Hawari (2001) dalam Larasati (2012) mengemukakan bahwa status pendidikan yang kurang pada seseorang akan menyebabkan orang tersebut lebih mudah mengalami stres dibanding dengan mereka yang status pendidikan yang lebih tinggi atau baik. Tingkat pendidikan turut menentukan mudah tidaknya seseorang menyerap dan memahami pengetahuan yang mereka peroleh. Dengan demikian ibu yang memiliki pendidikan kurang pastinya akan mengalami tingkat stresor yang tinggi dibandingkan dengan ibu yang memiliki pengetahuan yang tinggi hal ini dipengaruhi oleh kesiapan atau kemantapan ibu saat menjelang persalinan, ibu yang pengetahuannya luas atau baik akan lebih siap dibandingkan yang belum mengetahui atau tidak memiliki pengetahuan yang luas.

Pekerjaan IRT sebanyak 13 responden (72.2\%), Pedagang 1 responden $(5,6 \%)$, Karyawan Swasta 4 responden (22.2\%). Bekerja dapat mengalihkan perasaan cemas bagi ibu hamil, karena bekerja adalah aktivitas menyita waktu dan ibu hamil akan fokus ke pekerjaannya. Ibu hamil yang bekerja dapat berinteraksi dengan masyarakat sehingga dapat menambah pengetahuan, selain itu bekerja dapat menambah penghasilan keluarga untuk mencukupi kebutuhan selama kehamilan. Hasil penelitian ini sejalan dengan penelitian yang di lakukan oleh Astria (2009) yang menyatakan tidak ada hubungan antara pekerjaan dengan kecemasan ibu hamil.

Riwayat kehamilan yang Pertama sebanyak 10 responden (55.6\%), kehamilan yang kedua sebanyak 8 responden (44.4\%. Menurut Bobak (2005) mengungkapkan bahwa wanita nullipara secara aktif mempersiapkan diri untuk menghadapi persalinan. Seperti membaca buku, menghadiri kelas untuk orang tua dan berkomunikasi dengan wanita lain (ibu, saudara perempuan, teman, dan orang yang tidak dikenal), mereka akan mencari orang terbaik untuk memberi mereka nasihat, arahan, dan perawatan. Hasil penelitian ibu yang telah mendapatkan informasi atau arahan terkait dengan persiapan menjelang persalinan seperti pijat perineum menjadi lebih percaya diri, ibu tidak takut lagi akan proses persalinan karena ibu merasa lebih siap dalam mempersiapkan dirinya dengan diajarkan pijat perineum sehingga ibu tidak merasa takut atau was - was apabila terjadi robekan pada perineum, karena ibu akan merasa yakin bahwa ibu akan melahirkan dengan baik dan tidak mengalami robekan pada perineumnya.

Usia dari hasil penelitian didapatkan usia ibu paling banyak $<25$ sebanyak 13 responden $(72.2 \%), \quad 25-35$ sebanyak 3 responden $(22.2 \%),>35$ sebanyak 1 responden (5.6\%). Secara psikologis pada ibu hamil yang berusia $<20$ tahun, mempunyai kesiapan mental yang masih sangat kurang, sehingga ketika ibu hamil tersebut akan menghadapi persalinan banyak masalah psikologis yang muncul, seperti yang paling sering adalah perasaan cemas dan ketakutan akan proses persalinannya (Manuaba, 2010). Wanita yang secara alami mengandung di usia tua yaitu usia 30 atau 40 sering terganggu dengan kekhawatiran terhadap risiko kesehatan yang bisa terjadi pada mereka sendiri atau pada bayinya. Ketakutan berlebihan yang dirasakan ibu hamil bisa menimbulkan tekanan batin dan kecemasan yang lebih tinggi. Kegelisahan wanita usia di atas 30 tahun selama mengandung sering dipicu rentetan informasi tentang faktor risiko yang dapat membahayakan bagi ibu dan bayi yang dikandungnya (Carolan, 2014). Di dalam hasil penelitian ibu memiliki usia reproduksi yang baik dan bukan merupakan ibu resiko tinggi karena usia ibu lebih dari 25 tahun dan kurang dari 35 tahun, hanya terdapat 1 responden yang usianya lebih dari 35.

Berdasarkan hasil uji Mc Nemar bahwa Pengaruh pijat perineum pada ibu hamil 
trimester 3 terhadap tingkat kecemasan sebelum dan sesudah dilakukan pijat perineum. Didapatkan data responden yang mengalami kecemasan ringan sebelum diajarkan pijat perineum sebanyak 4 responden dan setelah diajarkan pijat perineum menjadi 0 responden. Sedangkan responden yang mengalami kecemasan sedang sebelum diajarkan pijat perineum sebanyak 11 responden dan setelah diajarkan pijat perineum menjadi sebanyak 3 responden. Dari hasil penelitian tampak bahwa Pijat perineum berpengaruh terhadap tingkat kecemasan pada ibu hamil trimester 3 .

Hal ini disebabkan karena pijat perineum dapat meningkatkan endorphin sehingga ibu hamil mengalami ketenangan dan rileks sehingga perineum menjadi elastic (Aprilia, 2010).

Pijat perineum merupakan salah satu mekanisme koping bagi ibu sehinggaibu berada dalam kenyamanan. Kondisi ini menyebabkan perineum menjadi elastis. Ditinjau dari segi psikologi pijat perineum menimbulkan perasaan senang dan nyaman sehingga dapat menurunkan kekhawatiran, ketakutan menghadapi persalinan serta dapat menurunkan nyeri.

\section{SIMPULAN DAN SARAN}

Hasil penelitian yang telah dilaksanakan menunjukan bahwa sebagian besar ibu mempunyai riwayat persalinan yang tidak bermasalah, dengan tingkat pendidikan rata rata SLTA, untuk riwayat pekerjaan rata - rata ibu rumah tangga, riwayat kehamilan mayoritas anak pertama, dan usia ibu mayoritas $>25$ tahun. Hasil penelitian menunjukan ada pengaruh pijat perineum pada ibu hamil trimester 3 terhadap tingkat kecemasan sebelum dan sesudah dilakukan pijat perineum. Rata - rata responden yang awalnya mengalami kecemasan ringan sebanyak 4 setelah diajarkan pijat perineum menjadi tidak ada yang mengalami kecemasan, sedangkan responden yang awalnya mengalami kecemasan sedang sebanyak 11 responden dan setelah diajarkan pijat perineum menjadi 3 responden yang mengalami kecemasan sedang dan 8 responden tingkat kecemasannya menjadi kecemasan ringan. Dengan demikian bahwa pijat perineum berpengaruh terhadap penurunan tingkat kecemasan pada ibu hamil trimester 3 .

\section{SARAN}

Peneliti menyarankan bagi fasilitas pelayanan kesehatan bahwa pijat perineum dapat diaplikasikan sebagai salah satu intervensi pada ibu hamil trimester 3 dalam mengurangi tingkat kecemasan pada ibu hamil saat menjelang persalingan. Selain itu pijat perineum dapat digunakan sebagai salah satu sumber referensi dalam ilmu keperawatan maternitas terkait pengembangan penatalaksanaan keperawatan mandiri untuk mengurangi kecemasan pada ibu hamil trimester 3 saat menjelang persalinan.

\section{DAFTAR PUSTAKA}

Aprilia, Y. 2010. Hipnosteri: Rileks, Nyaman Dan Nyaman Saat Hamil Dan Melahirkan. Jakarta.Gagas Media

Bobak. 2005. Buku Ajar Keperawatan Maternitas. Jakarta.EGC

Bobak, 2006. Buku Ajar Keperawatan Maternitas. Jakarta.EGC

Carolan, M. 2014. The Anxiety Facing Childbirth. Journalism \& Media Communication diakses tanggal 8 Mei 2014

Gadysa, G. 2009. Persepsi Ibu Tentang Metode Message.

http://luluvikar.wordpress.com/009/08/26/perse psi-ibu-tentang metod massage.

Hidayat.2006. Pengantar Kebutuhan Dasar Manusia Buku I. Jakarta: Salemba Medika

Indivara. 2009. Panduan Praktisi Senam Hamil. Jakarta:Rineka Cipta

Larasati, Inka Putri. 2012. Pengaruh Keikutsertaan Senam Hamil Terhadap Kecemasan Primigravida Trimester Ketiga Dalam Menghadapi Persalinan. Jurnal Biometrika dan kependudukan Vol 1 PP 26-32

Manuaba. 2010. Ilmu Kebidanan Penyakit Kandungan dan KB Pendidikan Bidan Edisi 2. Jakarta. EGC 
Rifdiani, Izfa. 2015. Pengaruh Paritas BBL, Jarak Kehamilan dan Riwayat Perdarahan Terhadap Kejadian Perdarahan Postpartum . Jurnal Berkala Epidemiologi Vol 4 No 3. September, $2016396-407$

Stuart, Gail W. 2007. Buku Saku Keperawatan Jiwa. Jakarta. EGC

Astria, Yonne, Irma nurbaeti, Catur Rosidati.

2009. Hubungan Karakteristik Ibu hamil

Trimester III Dengan Kecemasan Dalam

Menghadapi Persalinan Di Poliklinik

Kebidanan dan kandungan Rumah Sakit X

Jakarta. Majalah Keperawatan Vol 10 pp 38 -

48 